\title{
Dividend Policy and Stock Price Volatility in the Bangladesh Capital Market: An Experimental Analysis
}

\author{
Md. Shakhaowat Hossin ${ }^{1 *}$, Md. Farhad Ahmed ${ }^{2}$ \\ ${ }^{1}$ Assistant Professor, Department of Finance and Banking, Begum Rokeya University, Rangpur, Bangladesh \\ ${ }^{2}$ MBA, Department of Finance and Banking, Begum Rokeya University, Rangpur, Bangladesh
}

\begin{abstract}
DOI: $10.36348 /$ sjef.2020.v04i07.008
| Received: 01.07.2020 | Accepted: 12.07.2020 | Published: 28.07.2020

*Corresponding author: Md. Shakhaowat Hossin
\end{abstract}

\section{Abstract}

Commercial organizations in Bangladesh are experiencing rivalry among them because of economic struggle globally and attempting to remain competitive in these changeable economic surroundings. This paper intends to analyze the impact of dividend policy on the market price of stock in Bangladesh. The numbers of statistic community are 330 companies in Dhaka Stock Exchange. All 10 companies belong to the Food \& Allied, Ceramics and Cement industry listed at DSE index are included as the sample for a phase from 2008 to 2017. In this paper, Fixed Effect Model along with Random Effect Model has been used to estimate outcomes. Both Models are exercised on panel data for explaining the association between dividend payments and share prices after adjusting several variables including Earnings per Share, logarithm value of Profit after Tax, Growth of Asset and Dividend Payout Ratio. The study also checked both the Models and found Random Effect Model is more significant than Fixed Effect Model. Afterward, this paper applied the multicollinearity test to determine is there any correlation among the variables and found no multicollinearity. This paper found a weak form market exists in Bangladesh and investors choose stock dividend more than the cash dividend.

Keywords: Cash or Stock Dividend, Dividend Policy, Fixed Effect, Model, Random Effect Model, Stock Price.

Copyright @ 2020: This is an open-access article distributed under the terms of the Creative Commons Attribution license which permits unrestricted use, distribution, and reproduction in any medium for non-commercial use (NonCommercial, or CC-BY-NC) provided the original author and source are credited.

\section{INTRODUCTION}

Dividend policy is used as a means of valuing company from the investor's perspective. There are three major theories that attempt to explain investors demand for dividends. The first one is that high dividends are considered as current income of the shareholders. Dividends are also less risky and hence more valuable to investors than retained earnings. The second theory of dividend asserts that investors only care about total returns rather than receiving them in the form of dividends or in the price appreciation of a particular share. The third one implies that investors care about how their total returns are divided between dividends and market price appreciation primarily because of the tax involvement.

Dividend payment could provide a signal to the investors that the company is complying with good corporate governance practices. By distributing dividend, it able to attract investors and indirectly increase the company share price. This sort of company could easily raise funds through new share issuance for expansion which then would increase profits and increase share price.
When cash dividends are given the shareholders directly benefit from the cash income as part of their cash income after taxes are deducted from it. On the other hand when stock dividends are declared the shareholders of a company may keep the shares and hope that the company will be able to utilize the money not paid out in cash dividend to earn a better rate of return in the future.

The relation between intensity of market reaction and dividend changes is significantly influenced by the level of information risk. Different with most previous studies, we also consider the possibility that market may negatively interpret announcement of dividend changes because of different firm's characteristics. We thus show information contents of dividend changes are significantly different under different information risk scenarios. The primary goal of the shareholder aims to the maximization of profit. A company's dividend policy influences the decisions of that company's investors toward earnings from the investment. Maximizing profit of shareholders is the main intent focused on the dividend policy. 


\section{REVIEW OF LITERATURE}

When someone talks about the dividend policy, the name of Linter [1] comes first. Linter appealed with the question having a great interest until now. His inquiry is that "what decisions are taken by managers that influence the extent, form, and scheduling of payments of dividends?"

Modigliani-Miller [2] in the Dividend Irrelevance Theory, argue that the firm's value is determined by the investment policy and that the split between dividends and funds to be reinvested does not affect firm's value and thus its share prices assuming a perfectly competitive market, in which, in the absence of any corporate or personal taxes and transaction cost, an investor behaves and believed to be behaved rationally to maximize their wealth without any informational asymmetry and no investor is capable to influence security prices [3].

Black-Scholes[4] support the argument while Lumby and Jones [5], strike the view saying the name itself is misleading as they observe it is not the dividend that is irrelevant but the dividend pattern [5]. The postulates of their suggested perfect market is a fantasy, market imperfection is the most common experience the clientele ever encounter that makes dividend relevance in stock price fluctuations.

Jensen [6], on the other hand, proposed a theory which is widely known as the Free Cash Flow Hypothesis. He argues that a conflict of interest between shareholders and managers over the payment policies of these free cash flows could explain the stock price reaction. The theory predicts that stock prices will increase if there is unexpected dividend payment.

Gill, Biger, \& Tibrewala [7], studied the influence of profitability, growth, taxes, cash flow, risk and leverage on dividend payout ratio in the context service and manufacturing firms of America. They concluded that for service firms, dividend policy is influenced by growth, profitability and leverage. For manufacturing firms, dividend policy is influenced by taxes, profitability, and risk.

Jozwiak [8] investigated the factors influencing dividend policy of nonfinancial listed companies of Warsaw Stock Exchange of Poland. The factors studied include leverage, liquidity, profitability, size and risk. Findings reveal negative impact of leverage and profitability on dividend payout i.e. firms with high profitability pay low dividend to retain capital for future investment. Firms with high leverage pay low dividend due to high interest payments.

Shakhaowat M. Hossin [9], examined the relationship between inflation and economic growth in the context of Bangladesh and found a statistically significant long-run negative association between inflation and economic growth for the country as point out by a statistically significant long-run negative relationship running from Gross Domestic Product Deflator (GDPD) to GDP.

Alzomaia \& AlKhadhiri [10] examine the factors influencing dividend policy of nonfinancial listed companies of Saudi Arabia Stock Exchange (TASI). The factors studied include past dividend, earning per share, growth, leverage and size of firm. They found positive relationship of profitability and last year dividend with dividend payout decision.

Zameer et al. [11] examined the influence of selected variables on dividend policy of foreign and domestic banks listed at various stock exchanges of Pakistan. The factors studied include profitability, firm size, leverage, growth, and liquidity, agency cost, past dividend, risk, and ownership structure of the banks. Only four factors are found to have significant impact on dividend policy of banks.

Arif \& Akbar [12] studied the impact of five factors including profitability, size, tax, growth and lifecycle stage on dividend payout of nonfinancial firms of Pakistan.

Farman Ali Khan and Nawaz Ahmad [13] Journal of Financial Studies \& Research, They found that all factors significantly influence dividend payout. Profitability, size and investment opportunities positively influence dividend payout whereas tax negatively influences dividend payment decisions.

Kania \& Bacon [14] investigated the influence of selected variables on dividend policy of 543 firms using ordinary least square regression. They found that growth, expansion, risk, organizational and insider ownership are negatively associated with dividend policy. Positive relationship is found between debt to total asset ratio and dividend payout.

Khan, Burton \& Power [15] examined the view of different managers on dividend policy in Pakistan. Semi structured interview of 23 officials of Pakistani organization is conducted for the study. Findings reveal that dividend payout decisions in Pakistan are similar to developed countries like USA in many respects.

Shakhaowat M. Hossin and Shafiul M. Islam [16] examined the long-run equilibrium relationship between stock market development and economic growth of Bangladesh. The study demonstrated that a long run relationship exists between stock market development and economic growth in Bangladesh. The causality test results suggest a unidirectional causality running from stock market development to the economic growth. 
Mehta [17] examined the impact of risk, size, profitability, liquidity and leverage of firm on dividend payout. Findings reveal that profitability and size are the key factors in significantly changing dividend payout decision.

Nuhu [18] investigated the impact of profitability, investment opportunity sets, taxation, leverage, firm size, board size, board independence and audit type on dividend payout ratio. It was concluded that profitability, leverage, board independence, audit type, and board size are the key factors that significantly influence dividend payout in Ghana.

Maladjian \& Khoury [19] explored the impact of profitability, growth, liquidity and size of firm, leverage, risk, and previous year's dividends on dividend policy of Lebanese banks registered on Beirut Stock Exchange. They concluded that out of seven variables studied, five variables are statistically significant whereas profitability and liquidity are statistically insignificant.

Shakhaowat M. Hossin [20] analysed the relationship among interest rate reforms, financial development and economic growth of Bangladesh by using a financial deepening model and a simple trivariate causality model. The inference of this study was that a deregulated deposit rate of interest will raise financial depth and eventually enhance the economic growth of Bangladesh.

Rafique [21] examined the influence of size of firm, earnings, leverage, growth, profitability and corporate tax on dividend policy of Non-Financial firms listed in KSE100 index. She concluded that out of the six variables examined, only two variables including corporate tax and firm size are found to be significant.

Another study performed to find out the effect of policy associated with dividend on the price of the share by Hussainey, Mgbame and Chijoke-Mgbame [22] .The findings of their paper explored that share price movements have an active link with dividend income and a negative link with Dividend Payout Ratio.

In Bangladesh, Al-Hasan, Asaduzzaman and Karim [23] performed a study of 28 companies from automobile, cement, and textile and pharmacy industry listed in DSE. They found a significant association between the market price per share and dividend per share. Their analysis also showed that dividend policy has a substantial impact on the market price per share. Another study conducted by Mamun, Haque and Ahshanul [24] found that dividend disbursement convey a message to the market, which could adjust share price but market failed to adjust accordingly in a balanced way for the firms they studied. The results they found are similar to the results found in an earlier study on the capital market of Bangladesh conducted by Uddin and Chowdhury [25].

Nautiyal and Kavidayal[26] studied empirical findings on the impact of institutional variables such as Earnings per share (EPS), Economic value added (EVA), dividend payout (DIVP) and dividend per share (DPS) on firm's stock market price performance. The study confirmed that performance of companies fundamental ratios will be essential and immensely helpful to investors and analysts in assessing the better stocks that belong to different industry groups.

\section{Kumar \& Ranjani}

explored dividend behaviour of Indian manufacturing and service sector firms and to investigate similarities/differences between the same. Analysis suggests that firm size and cash holdings have significant positive relationship to dividend paid, whereas age and net working capital are negatively significant for dividend declarations in the service sector.

\section{OBJECTIVES}

The objective of the study is to define the influence of dividend policy on the share prices of Food and Allied, Ceramics sector and Cement sector in Bangladesh during 2008 to 2017 . What is the effect of a firm's dividend policy on the current stock price but also to the investors and economist? Investors plan to make their portfolio by considering the dividend policy and economists seek to understand and make valuation the functioning of the capital market. This importance make questions, how much impact causes due to dividend policy on the price of the stock?? Is there any impression of Earnings per Share, Return on Equity or Growth of Asset on the stock prices in the Dhaka Stock Exchange?

\section{RATIONALE OF THE STUDIES}

This article presents a framework of analysis for examining the impact of dividend policy on the share prices of Food and Allied, Ceramics sector and Cement sector in Bangladesh. This paper put out with an analysis of quite a lot of literature on the dividend policy and stock prices association. Which provided an insight into the modelling of the relationship among the Stock Price Volatility (SPV), Cash Dividend (CD), Stock Dividend (SD), Profit after Tax (PAT), Earnings Per Share (EPS), Return on Equity (ROE), Growth of Asset (GA) and Dividend Payout Ratio (DPR) of the firm. The underneath idea of this study is to what extent dividend policy affect stock price.

\section{METHODOLOGY Sources of Data}

The study used secondary data. All 10 listed firms from the Food \& Allied, Ceramics and Cement industry in the Dhaka Stock Exchange Limited (DSE) are taken as the sample for 10 years from 2008 to 2017. 
There are 4 companies in Cement industry and 3 Companies in Food \& Allied, and 3 Companies in Ceramics industry listed in the DSE. The required data are primarily compiled from the following sources:

- Audited Financial Statements of the companies.

- Stock price index in DSE and daily closing stock prices were collected from the DSE data archive.

- Lanka Bangla Financial Portal for collecting dividend history.

\section{Definition of Variables}

Stock Price Volatility (SPV) is used as a dependent variable in this paper by following method developed by Parkinson to obtain the SPV.

$$
\left(H_{i t}-L_{i t}\right) \div\left(H_{i t}+L_{i t}\right) \div 2 \ldots \text { (i) }
$$

In this formula, (i) $H_{i t}$ represents the highest stock price of the firm ' $\mathrm{i}$ ' in the year ' $\mathrm{t}$ ' and $L_{i t}$ denotes lowest stock price of the firm ' $i$ ' in the year ' $t$ '.

Cash Dividend (CD) has the direct link with stock prices either positive or negative. Mogere [28] found a weak, insignificant relationship between CD and stock prices. Stock Dividend (SD) has an influence on stock price and may show a positive or negative reflection. Horne, Wachowicz [29] and Kuhlemeyer [30] described the impact of SD by getting a negative relationship between the number of shares and share prices and EPS without affecting the firm's value.

Another important variable, Profit after Tax has a positive and meaningful relationship with stock price. Later, the association is supported by Adesola and Okwong [31], Khan, Aamir, Qayyum, Nasir and Khan [32], Pani [33], and Ahmed and Javid [34]. Many researchers used EPS as a control variable like Adesola and Okwong [31], Allen and Rachim [35], Baskin [36], Liu and $\mathrm{Hu}$ [37], and Chen, Liu and Huang [38]. They concluded that EPS has a positive and significant correlation with the stock price. On the other hand, Adefila, Oladipo and Adeoti [39] did not get any significant association between EPS and stock price.

Return on Equity (ROE) is used as an important variable in this paper. According to previous studies conducted by Khan, Aamir, Qayyum, Nasir and Khan [32], Liu and Hu [37], and Ling, Mutalip, Shahrin and Othman [40] and there has a positive association between ROE and stock price.

The Growth of Asset (GA) is used in this study as a key control variable and obtained as under,
GA $=\Delta$ Asset $_{i t} \div$ Asset $_{i t-1}$

In this formula, $\Delta$ Asset $_{i t}$ indicates a change of total assets for the firm ' $\mathrm{i}$ ' in the current year of ' $\mathrm{t}$ ' than the previous year of ' $t-1$ ' and Asset $_{\mathrm{it}-1}$ denotes total assets of the firm ' $i$ ' in the year ' $t-1$ '.

In this study, Dividend Payout Ratio (DPR) is used as one of the important independent factors by considering a proxy variable of dividend policy. The amount of cash dividend per share is divided by the net income (after tax) available for each shareholder for calculating DPR. The formula is as under,

$$
\text { DPR }=D P S_{i t} \div E P S_{i t}
$$

In this formula, $D P S_{i t}$ indicates dividend per share of the firm ' $\mathrm{i}$ ' in the year' $\mathrm{t}$ ' and $E P S_{i t}$ denotes earnings per share of the firm ' $i$ ' in the year ' $t$ '.

\section{Specification of Model}

Fixed Effect Model together with Random Effect Model regressions are used to analyze panel data. In the study, Fixed Effect Model is employed for controlling the stable features of the firms for a static period. This method is famous for eradicating the biased data and eventually gives good outcomes statistically. This model also works better when variations exist within samples. When the features of the sample vary, Random Effect Model is used. The appeal of firms i.e. volume, capital size, the number of stockholders, category of business, and company's income are not similar for all enterprises. For that reason, this technique is fit to explicate the differentiation among the corporate bodies. Similar approaches are also applied in their researches by Hussainey, Mgbame and Chijoke-Mgbame [22], Khan, Aamir, Qayyum, Nasir and Khan [32], Rashid and Rahman [41], and Nazir, Nawaz, Anwar and Ahmed[42].

The intent of this paper is to reveal the impact between share prices and dividend policy after the adjustment of Earnings per Share, Dividend Payout Ratio as well as Growth of Asset. This study also attempted to identify the relation of other key variables such as Profit after Tax, Stock Dividend and Return on Equity. The augmentation of these variables will amplify stock prices of the Food \& Allied, Ceramics and Cement sector in Bangladesh.

The understated equation of regression is applied in this paper.

$$
S V P=\alpha_{0}+\alpha_{1} C D_{1}+\alpha_{2} S D_{2}+\alpha_{3} P A T_{3}+\alpha_{4} E P S_{4}+\alpha_{5} R O E_{5}+\alpha_{6} G A_{6}+\alpha_{7} D P R_{7}+\varepsilon_{t}
$$




\section{Data Processing and Analyzing Technique}

Stata 14 and Microsoft Excel are used to process and analyze the data. Descriptive analysis is used in this study. Dependent and independent variables are analyzed by using correlation as well as linear regression i.e. Fixed Effect Regression and Random
Effect Regression. Then Hausman Test [43], is performed for checking which model is effective. Regression analysis is mainly used to analyze the relationship of dividend policy and share price of the companies.

\section{ANALYSIS AND DISCUSSION Descriptive Statistics}

Table-1: Descriptive Statistics

\begin{tabular}{|c|c|c|c|c|c|}
\hline Variables & Obser. & Mean & Min & Max & Std. Dev. \\
\hline Stock Price Volatility (SPV) & 80 & .8223 & .12 & 1.98 & .48580 \\
\hline Cash Dividend (CD) & 80 & 16.825 & 0 & 38 & 11.0416 \\
\hline Stock Dividend (SD) & 80 & 85.650 & 0 & 200 & 46.8712 \\
\hline Profit After Tax (PAT) & 80 & 1.937 & -.95 & 9 & 2.0920 \\
\hline Earnings Per Share (EPS) & 80 & 17.941 & -8.13 & 45 & 12.1718 \\
\hline Return on Equity (ROE) & 80 & .0005 & -4.79 & .91 & 1.1377 \\
\hline Growth of Asset (GA) & 80 & .8842 & 0 & 1.75 & .47102 \\
\hline Dividend Payout Ratio (DPR) & 80 & .3242 & -16.67 & 5.26 & 6.2476 \\
\hline
\end{tabular}

Source: Author's own estimation using Stata 14.

Above table-1 shows that, Stock Dividend has the maximum mean value graded at 85.65 while Stock Price Volatility has an average value of 0.82 . The minimum mean value stays at .0005 , which belongs to return on Equity. The value of standard deviation can show the divergence in datasets. The largest standard deviation value is 46.8712 for Stock Dividend. It indicates a great change in the stock trading prices of Food and Allied, Ceramics and Cement industry in Bangladesh is by cause of Stock Dividend. The lowest standard deviation value belongs to Growth of Asset with 0.471 , which indicates Growth of Asset causes smallest change in the share market values of Food and Allied, Ceramics and Cement industry in Bangladesh.

\section{Correlation Matrix}

Table 2 displays the relationship amongst the different descriptive variables and stock prices, which is the dependent variable. Pearson Correlation technique is employed for this mission.

Table-2: Correlation matrix

\begin{tabular}{|l|l|l|l|l|l|l|l|l|}
\hline & $\boldsymbol{S P V}$ & $\boldsymbol{C D}$ & $\boldsymbol{S D}$ & $\boldsymbol{P A T}$ & $\boldsymbol{E P S}$ & $\boldsymbol{R O E}$ & $\boldsymbol{G A}$ & $\boldsymbol{D P R}$ \\
\hline SPV & 1 & & & & & & & \\
\hline CD & $0.070^{* *}$ & 1 & & & & & & \\
\hline SD & $-0.129 * *$ & $0.044^{*}$ & 1 & & & & & \\
\hline PAT & $0.201^{* *}$ & 0.059 & $0.089^{*}$ & 1 & & & & \\
\hline EPS & -0.084 & $0.099^{*}$ & -0.050 & $-0.016^{* * *}$ & 1 & & & \\
\hline ROE & $0.038^{*}$ & $0.127^{* * *}$ & -0.221 & $0.160^{* *}$ & 0.018 & 1 & & \\
\hline GA & -0.074 & -0.116 & 0.069 & 0.036 & -0.109 & -0.151 & 1 & \\
\hline DPR & -0.119 & -0.145 & $-0.032^{*}$ & 0.174 & -0.132 & -0.054 & 0.010 & 1 \\
\hline
\end{tabular}

Source: Author's own estimation using Stata 14.

*** 1 percent significant level, $* * 5$ percent significant level, $* 10$ percent significant level $(2$ tailed $)$

Stock prices of Food and Allied, Ceramics and Cement industry in Bangladesh have a substantial relationship with the Stock Dividend and positive relationship with ln value of Cash Dividend and Profit after Tax. Stock prices also have similar link with Return on Equity. These relations are confident at 95 percent level and 90 percent level of confidence. There is a significant relationship between the Earning per Share and $\ln$ value of Profit after Tax and Cash Dividend at 1 percent and 10 percent significance level and a negative correlation with Stock Dividend and Growth of Asset. Logarithm value of Cash Dividend and Profit after Tax have significant positive relation with Stock Dividend while Dividend Payout Ratio has significant negative relation with Stock Dividend both at 10 percent degree of significance. Both logarithm value of Cash Dividend and Profit after Tax have a significant link with Return on Equity having 1 percent and 5 percent significance level, and negative link with Dividend Payout Ratio. The Growth of Asset and Dividend Payout Ratio have an insignificant negative relationship with Stock Price Volatility (SPV).

\section{Fixed Effect Model}

Table 3 displays the outcomes of Fixed Effect Model. Additionally, these outcomes explicate the importance of every single factor of dividend decision and policy included within the model as well as the importance carried by the model as a whole. 
Table-3: The Result of Fixed Effect Model

\begin{tabular}{|c|c|c|c|c|}
\hline Variables & Coefficient & Std. Err. & $\mathbf{t}$ & $\mathbf{P}>|\mathbf{t}|$ \\
\hline Constant & .8625673 & .2103896 & 4.10 & 0.000 \\
\hline $\mathrm{CD}$ & .0011998 & .0055137 & 0.22 & 0.828 \\
\hline SD & -.0003165 & .0013111 & -0.24 & 0.810 \\
\hline PAT & -.0545798 & .0294967 & -1.85 & 0.069 \\
\hline EPS & -.0011448 & .0050433 & -0.23 & 0.821 \\
\hline ROE & .0220066 & .0544058 & 0.40 & 0.687 \\
\hline GA & .1045476 & .1420779 & 0.74 & 0.464 \\
\hline DPR & -.003604 & .0098935 & -0.36 & 0.717 \\
\hline & & $F(7,65)=0.66$ & \multicolumn{2}{|c|}{ Prob. $>\mathrm{F}=0.7054$} \\
\hline
\end{tabular}

\section{Equation under Fixed Effect Model:}

According to the outcomes of Fixed Effect Model Cash Dividend (CD), Return on Equity (ROE) (PAT), Earning per Share (EPS) and Dividend Payout Ratio (DPR) have a negative relationship to market prices of share in this model.

\section{Random Effect Model}

The outputs of Random Effect Model are shown in Table 4. The outcomes of Random Effect and Growth of Asset (GA) have a positive association with share prices while logarithm value of Stock Dividend (SD), Profit after Tax Method justify the outputs presented in Table 2. These results explicate the significance of every single factor of dividend policy within the model as well as the weight carried by the model as a whole.

$$
S V P=.862+.001 C D_{t}-.0003 S D_{t}-.055 P A T_{t}-.001 E P S_{t}+.022 R O E_{t}+.104 G A_{t}-.003 D P R_{t}+\varepsilon_{t}
$$

Table-4: The Result of Random Effect Model

\begin{tabular}{|l|l|l|l|l|}
\hline Variables & Coefficient & Std. Err. & $\mathbf{z}$ & $\mathbf{P}>|\mathbf{z}|$ \\
\hline Constant & .8668635 & .2049413 & 4.23 & 0.000 \\
\hline CD & .0012126 & .0052149 & 0.23 & 0.816 \\
\hline SD & .0000341 & .0012404 & 0.03 & 0.978 \\
\hline PAT & -.0473544 & .0279073 & -1.70 & 0.090 \\
\hline EPS & -.0011027 & .0046769 & -0.24 & 0.814 \\
\hline ROE & .0226369 & .0523452 & 0.43 & 0.665 \\
\hline GA & .0488129 & .1215326 & 0.40 & 0.688 \\
\hline DPR & -.0036529 & .0093061 & -0.39 & 0.695 \\
\hline \multicolumn{2}{|r|}{$\mathrm{Chi}^{2}(7)=3.65$} & Prob. $>$ chi $^{2}=0.8194$ \\
\hline
\end{tabular}

Source: Author's own estimation using Stata 14.

\section{Equation under Random Effect Model:}

Random Effect Model found Cash Dividend (CD), Stock Dividend (SD), Return on Equity (ROE) and Growth of Asset (GA) has a positive relationship with stock prices. Besides Profit after Tax (PAT), Earnings per Share (EPS) along with Dividend Payout Ratio (DPR) have a negative correlation to market prices of share in this model.

These results ensure that investors gave preference to the Profit after Tax (PAT) and Growth of Asset (GA) for these sectors from 2008 to 2017 time frame. Investors mostly show their less interest in Cash Dividend, Stock Dividend and Dividend Payout Ratio.

Table 5 presents the output of Hausman Test [43] to resolve which model is more acceptable than the other. In this test, the null hypothesis was Random Effect Model is significant and alternative hypothesis was Fixed Effect Model is significant. Here, the output has the value of chi-square is 1.91 with a probability of 0.9648 which is more than 0.05 .

$$
S P V=.867+.001 C D_{t}+.00003 S D_{t}-.04 P A T_{t}-.001 E P S_{t}+.02 R O E_{t}+.048 G A_{t}-.003 D P R_{t}+\varepsilon_{t}
$$


Table-5: The Result of Hausman Test

\begin{tabular}{|c|c|c|c|c|}
\hline Variables & Fixed & Random & Difference & S.E. \\
\hline $\mathrm{CD}$ & .0011998 & .0012126 & -.0000127 & .0017905 \\
\hline SD & -.0003165 & .0000341 & -.0003505 & .0004249 \\
\hline PAT & -.0545798 & -.0473544 & -.0072255 & .009552 \\
\hline EPS & -.0011448 & -.0011027 & -.000042 & .0018873 \\
\hline $\mathrm{ROE}$ & .0220066 & .0226369 & -.0006303 & .0148314 \\
\hline GA & .1045476 & .0488129 & .0557347 & .0735931 \\
\hline DPR & -.003604 & -.0036529 & .000049 & .0033585 \\
\hline & \multicolumn{4}{|c|}{ Null Hypothesis : Random Effect Model is significant } \\
\hline & \multicolumn{4}{|c|}{ Alternative Hypothesis : Fixed Effect Model is significant } \\
\hline & \multicolumn{4}{|c|}{ Test: $\mathrm{H}_{0}$ : Dissimilarity in coefficients is not systematic } \\
\hline & \multicolumn{4}{|c|}{\begin{tabular}{rl|l|}
$\operatorname{chi}^{2}(7)$ & $=1.91$ & Prob. $>$ chi $^{2}=0.9648$
\end{tabular}} \\
\hline
\end{tabular}

Here, it was found that Random Effect Model is more significant than Fixed Effect Model to describe the relation among the variables used in this study. Random Effect Model is appropriate for this study, and Hausman Test reflects the above statement.

Results of Random Effect Model represent Cash Cash Dividend (CD), Stock Dividend (SD), Return on Equity (ROE) and Growth of Asset (GA) have a positive link with the share price and Profit after Tax (PAT), Earnings per Share (EPS) along with Dividend Payout Ratio (DPR) have a negative link with the share prices of Food and Allied, Ceramics and Cement industry sector in the capital market of Bangladesh. It is noticeable that Stock Dividend and Return on Equity have insignificant relationship with share prices, which indicates the existence of the weak form market and the behavioral problem of investors in the market studied by this paper.

Return on Equity has no significant relationship with the market price of the share. From the Random Effect Approach, it is one of the important things that share price has a positive consequence with Return on Equity in this study. This positive association proved that the management of organizations is using the shareholders' funds efficiently.

\section{CONCLUSION}

The empirical evidence based on the Random Effect Model shows that there is a positive relation of Cash Dividend (CD), Stock Dividend (SD), Return on Equity (ROE) and Growth of Asset (GA) with stock prices. And Profit after Tax (PAT), Earnings per Share (EPS) along with Dividend Payout Ratio (DPR) showed the negative involvement with the share prices in Bangladeshi the Food \& Allied, Ceramics and Cement industry sector.

Hence, it is proposed and recommended that this paper will assist the prospective researchers to examine other industries in Bangladesh with a variety of size and with a contrast of dividend distributing and non-distributing firms. This study will also serve them to conduct more studies on different factors on dividend policy, which may anticipate the aptitude and latency of capital markets, economic circumstances, and stock price volatility in the growing economy like Bangladesh.

\section{MANAGERIAL IMPLICATIONS}

The first significant policy implication arising out of the empirical findings in the article is that policy makers of the firms should formulate strategy for the factors for which investors give preference as to the Profit after Tax (PAT) and Growth of Asset (GA). Investors mostly show their less interest in Cash Dividend, Stock Dividend and Dividend Payout Ratio for these sectors from 2008 to 2017 time frame.

\section{LIMITATIONS AND FUTURE RESEARCH}

The analysis of this article is confined only to a limited number of variables as Stock Price Volatility (SPV), Cash Dividend (CD), Stock Dividend (SD), Profit after Tax (PAT), Earnings Per Share (EPS), Return on Equity (ROE), Growth of Asset (GA) and Dividend Payout Ratio (DPR).So the study can be conducted by adding more variables in the analysis. More time periods can be considered for further research.

Dividend payout policy is one of the major unsolved problems of corporate finance which observes more research in order to increase understanding of the subject. The same country, incorporating almost the same variables but different industries has come up with somewhat different results. This conflicting results demand more research that could clarify such relationships.

\section{ACKNOWLEDGEMENT}

I am grateful to the anonymous referees of the journal for their extremely useful suggestions to improve the quality of the article. Usual disclaimers apply. 


\section{Declaration of Conflicting Interests}

The author declared no potential conflicts of interest with respect to the research, authorship and/or publication of this article.

\section{Funding}

The author received no financial support for the research, authorship and/or publication of this article.

\section{ORCID iD}

Md Shakhaowat Hossin. https://orcid.org/00000002-5182-7986

\section{REFERENCES}

1. Lintner, J. (1956). Distribution of incomes of corporations among dividends, retained earnings, and taxes. The American economic review, 46(2), 97-113.

2. Miller, M. H., \& Modigliani, F. (1961). Dividend policy, growth, and the valuation of shares. the Journal of Business, 34(4), 411-433.

3. Pike, R. (2012). Corporate finance and investment: decisions and strategies: text book.

4. Black, F., \& Scholes, M. (1974). The effects of dividend yield and dividend policy on common stock prices and returns. Journal of financial economics, 1(1), 1-22.

5. Lumby, S., \& Jones, C. (1999). Investment appraisal and financial decisions (Doctoral dissertation, Univerza v Mariboru, Ekonomskoposlovna fakulteta).

6. Jensen, M. C. (1986). Agency costs of free cash flow, corporate finance, and takeovers. The American economic review, 76(2), 323-329.

7. Gill, A., Biger, N., \& Tibrewala, R. (2010). Determinants of dividend payout ratios: evidence from United States. The Open Business Journal, 3(1) 8-14.

8. Kaźmierska-Jóźwiak, B. (2015). Determinants of dividend policy: evidence from polish listed companies. Procedia economics and finance, 23, 473-477.

9. Hossin, M. S. (2015). The relationship between inflation and economic growth of Bangladesh: An empirical analysis from 1961 to 2013. International Journal of Economics, Finance, and Management Sciences, 13(5) 426-434.

10. Alzomaia, T. S., \& Al-Khadhiri, A. (2013). Determination of dividend policy: The evidence from Saudi Arabia. International Journal of Business and Social Science, 4(1) 12.

11. Zameer, H., Rasool, S., Iqbal, S., \& Arshad, U. (2013). Determinants of dividend policy: A case of banking sector in Pakistan. Middle-East Journal of Scientific Research, 18(3), 410-424.

12. Arif, A., \& Akbarshah, F. (2013). Determinants of dividend policy: a sectoral analysis from Pakistan. International Journal of Business and Behavioral Sciences, 3(9), 16-33.
13. Khan, F. A., \& Ahmad, N. (2017). Determinants of dividend payout: an empirical study of pharmaceutical companies of pakistan stock exchange (PSX). Journal of Financial Studies \& Research, 1-16.

14. Kania, S. L. \& Bacon F. (2005). What factors motivate the corporate dividend decision? Am. Soc. Bus. Behav. Sci. E-J., 1(1), 97-107.

15. Khan, N. U., Burton, B. M., \& Power, D. M. (2011). Managerial views about dividend policy in Pakistan. Managerial Finance. 37(10) 953-970.

16. Hossin, M. S., \& Islam, M. S. (2019). Stock Market Development and Economic Growth in Bangladesh: An Empirical Appraisal. International Journal of Economics and Financial Research, 5(11), 252-258.

17. Mehta, A. (2012). An empirical analysis of determinants of dividend policy-evidence from the UAE companies. Global review of accounting and finance, 3(1), 18-31.

18. Nuhu, E. (2014). Revisiting the determinants of dividend payout ratios in Ghana. International Journal of Business and Social Science, 5(8).

19. Maladjian, C., \& Khoury, R. E. (2014). Determinants of the dividend policy: an empirical study on the Lebanese listed banks. International Journal of Economics and Finance, 6(4), 240-256.

20. Hossin, M. S. (2020). Interest Rate Deregulation, Financial Development and Economic Growth: Evidence from Bangladesh. Global Business Review.https://doi.org/10.1177/0972150920916564

21. Rafique, M. (2012). Factors affecting dividend payout: Evidence from listed non-financial firms of Karachi stock exchange. Business Management Dynamics, 1(11), 76

22. Hussainey, K., Mgbame, C. O., \& Chijoke Mgbame, A. M. (2011). Dividend policy and share price volatility: UK evidence. The Journal of risk finance, 12(1), 57-68.

23. Al-Hasan, M. A., Asaduzzaman, M., \& Karim, R. A. (2013). The effect of dividend policy on share price: An evaluative study. IOSR Journal of Economics and Finance, 1(4), 6-11.

24. Mamun, A., Hoque, N., \& Mamun, A. M. A. (2013). Stock Price Reaction to dividend announcement: the case of Bangladesh Capital market. Journal of Economics and Sustainable Development, 4(8), 89-98.

25. Uddin, M. H., \& Chowdhury, G. M. (2005). Effect of dividend announcement on shareholders' value: Evidence from Dhaka Stock Exchange. Journal of business research, 7(1), 61-72.

26. Nautiyal, N., \& Kavidayal, P. C. (2018). Analysis of institutional factors affecting share prices: The case of national stock exchange. Global Business Review, 19(3), 707-721.

27. Kumar, S., \& Ranjani, K. S. (2018). Dividend behaviour of Indian-listed manufacturing and service sector firms. Global Business Review, 20(1), 179-193. 
28. Mogere, I. K. (2016). The relationship between dividend policy and stock return volatility of companies listed at the Nairobi Securities Exchange.

29. Van Horne, J. C., \& Wachowicz, J. M. (2005). Fundamentals of financial management. Pearson Education.

30. Kuhlemeyer, G. A. (2004). Fundamentals of financial management.

31. Adesola, W. A., \& Okwong, A. E. (2009). An empirical study of dividend policy of quoted companies in Nigeria. Global Journal of Social Sciences, 8(1), 85-101.

32. Khan, K. I., Aamir, M., Qayyum, A., Nasir, A., \& Khan, M. I. (2011). Can dividend decisions affect the stock prices: A case of dividend paying companies of KSE. International Research Journal of Finance and Economics, 76(68), 69-74.

33. Pani, U. (2008). Dividend Policy and Stock Price Behaviour in Indian Corporate Sector: A panel data approach. Retrieved from Indian Institute of Technology: http://ssrn. com/abstract, 1216171.

34. Ahmed, H., \& Javid, A. Y. (2008). The determinants of dividend policy in Pakistan.

35. Allen, D. E., \& Rachim, V. S. (1996). Dividend policy and stock price volatility: Australian evidence. Applied financial economics, 6(2), 175188.

36. Baskin, J. (1989). Dividend policy and the volatility of common stocks. Journal of portfolio Management, 15(3), 19.
37. Liu, S., \& Hu, Y. (2005). Empirical analysis of cash dividend payment in Chinese listed companies. Nature and Science, 1(3), 65-70.

38. Chen, D. H., Liu, H. H., \& Huang, C. T. (2009). The announcement effect of cash dividend changes on share prices: An empirical analysis of China. Chinese Economy, 42(1), 62-85.

39. Adefila, J. J., Oladipo, J. A., \& Adeoti, J. O. (2004). The effect of dividend policy on the market price of shares in Nigeria: case study of fifteen quoted companies. International Journal of Accounting, 2(1), 1-10.

40. Ling, F. S., Abdull Mutalip, M. L., Shahrin, A. R., \& Othman, M. S. (2007). Dividend policy: evidence from public listed companies in Malaysia, Int. Rev. Bus. Res. Pap., 4(4), 208-222.

41. Rashid, A., \& Rahman, A. A. (2008). Dividend policy and stock price volatility: evidence from Bangladesh. The Journal of Applied Business and Economics, 8(4), 71.

42. Nazir, M. S., Nawaz, M. M., Anwar, W., \& Ahmed, F. (2010). Determinants of stock price volatility in karachi stock exchange: The mediating role of corporate dividend policy. International Research Journal of Finance and Economics, 55(55), 100-107.

43. Hausman, J. A. (1978). Specification tests in econometrics. Econometrica: Journal of the econometric society, 46(6), 1251-1271. 